\title{
VALUE MANAGEMENT IN NON-PROFIT ORGANIZATIONS - THE FIRST STEP
}

\author{
Jarosław DOMAŃSKI
}

Faculty of Management

Warsaw University of Technology, 02-524 Warszawa, Poland

J.Domanski@wz.pw.edu.pl

\begin{abstract}
This article represents a initial observation on implementing a value management concept for nonprofit organizations. Introducing strategic management in non-profit companies is becoming inevitable in order to build up their competitiveness on the non-profit services market. In the first part of this article the key stakeholders of non-profit organizations are identified. The second part is an attempt to present the principal value drivers of non-profit organizations. The groups of key stakeholders that are the most important recipients of the value created by the individual drivers have been assigned to the principal value drivers.
\end{abstract}

Keywords: value, stakeholders, non-profit, strategic management, value drivers, value management.

\section{Introduction}

In the last twenty years the number of non-profit organizations has increased enormously; the scope of their activities has broadened as well. Such organizations are involved in almost every aspect of human activity throughout the world. One no longer sees non-profit organizations only engaged in marginal activities of dubious quality. They play an important role in almost every society, assisting in providing health care, in development of education and social well-being [39].

As Drucker [17] notes, forty years ago the very word "management" was treated as something inappropriate by non-profit organizations. It implied "business", with which such organizations had nothing in common. Bogacz-Wojtanowska [7] notes that often, according to many practitioners, the opinion that there is no need to manage non-profit organizations still lingers to the present day. She also writes, however, that when nonprofit organizations started to become one of the main socio-political forces in the world in the 1990s how they function and the challenges related to their effective management became highly relevant.

Managing the non-profit organization must and should lead to its strategic, market and pro-ecological orientation. This is an essential requirement for creating its future competitiveness on the non-profit services market. Competitiveness requires non-profit organizations to think strategically and engage in long-term planning, which lead to their opening up to the non-profit services market. They need to learn and create their own visions of the future, becoming in the process more intelligent organizations, serving their environment [44]. The strategy plays a special role in non-profit organiza- tion management - it allows for the transformation of actors' intentions, contained in mission plans, into real achievements [16].

In various definitions of management and strategic management, the key goal for the functioning of an enterprise is increasing its value. The value of a company is understood as the sum of benefits for its ownersstockholders or shareholders. All management efforts should therefore focus on maximizing the satisfaction of the owners of the enterprise. The majority of the largest organizations on the Fortune 500 list are managed through value. It is a widely accepted management concept, and one which means that clients return, also inspiring employees to work to their best every day, leaving owners proud and satisfied with their profits [6]. If the concept works so well among business organizations there is no reason why the third sector should not benefit from their positive experience.

The main aim of this article is to make a first step towards transferring the concept to third sector organizations. In adapting value management to the conditions of non-profit organizations one needs to consider the following very important elements: who are the key value stakeholders of the non-profit organizations and what are the key factors influencing the value of the non-profit organization?

The first part [of the article] identifies the key stakeholders of non-profit organizations. Brief literature research was made to identify stakeholders, both in the business sector, as well as among authors writing about the third sector. The second, and the most important part is an attempt to present the principal value drivers in non-profit organizations. Rappaport's (1999) approach to this issue is presented, as well as the ap- 
proach of other, Polish, authors. Based on the literature research, the author of the article shows that the factors influencing value are undoubtedly to be found in the organization's resources, mostly among intangible assets. The groups of key stakeholders that are the most important recipients of the value created by individual drivers have been assigned to the principal value drivers. A brief presentation of each of the identified group of drivers focuses on their role in non-profit organizations. Identification of key value drivers is an important activity for each organization, including those from the $3^{\text {rd }}$ sector. Determination of the key value drivers and then, acting from the need to increase their value, should contribute to increasing the efficiency and effectiveness of the activities of non-profit organizations.

\section{Stakeholders of non-profit organizations}

In the private sector activities aiming at increasing the value of individual enterprises are mostly oriented towards their owners, who are usually their stockholders as well. Stockholders, as people possessing part of the company's assets, are mainly interested in increasing its value, above all by raising its stock price. Only later other stakeholders, such as employees, suppliers, consumers, competitors and other organizations working in the company's environment, are taken into account.

Clarkson [13] describes stakeholders as persons or groups that have, or claim, ownership rights or interests in a corporation and its activities, past, present, or future. He also lists the following groups: employees, shareholders, customers, and others. Primary stakeholder groups are typically comprised of shareholders and investors, employees, customers and suppliers, together with what is defined as the public stakeholder group: the governments and communities that provide infrastructures and markets, whose laws and regulations must be obeyed and to whom taxes and other obligations may be due [13].

In relation to non-profit organizations, the recognized key stakeholders are: government, oversight agencies, private donors and foundations, clients, the media and the public at large [26]. This list may be amended with personnel, beneficiaries, volunteers and members, included by Harris, Mainelli and O'Callaghan [20]. The key to success for a non-profit organization is satisfying key stakeholders' interests, according to their criteria for measuring satisfaction. Key stakeholders are those whose satisfaction is crucial to the generation of sufficient support, legitimacy and the resources sufficient to ensure the organization's viability and effectiveness [10].

It is difficult to talk about owners in the case of nonprofit organizations, since despite possessing assets most often they do not issue shares. The organization itself is the owner of the assets, if it is a legal entity. The group of people who are founder members and members of particular organizations are in a sense similar to owners of private companies. Their motivation, however, is not to increase the value of the company, but the extent to which the goals of the organization are reached.

The recipients of the organization's activities form another group of stakeholders. In many cases the recipients are at the same time members of a given organization (e.g. in self-help organizations). However, when the organizations provide services externally the recipients are of course the "purchasers" of those services, or persons and institutions who benefit from the activity of a given non-profit organization. It is also difficult to assume that a change in the value of a donor is of any importance for the beneficiary.

However, the purchasers of services, for example of cultural institutions (sometimes also counted among non-profit organizations) are guests and the public. In this case the value will be of some importance, influencing the decision to visit one or another exhibition, or theatre etc. One should therefore assume that the importance of the value of a non-profit organization for the client will depend on the profile of the organization's activity.

Meanwhile, the value of the organization will undoubtedly be important for all people and institutions that are specific "suppliers" for non-governmental organizations. These include of course current and potential sponsors, donors, benefactors, both institutional and natural persons and local government units, central government bodies, etc. The value of the organization applying for support, as perceived by suppliers, certainly influences the decisions they make. They are much more willing to support institutions that enjoy a good reputation and act efficiently, in other words the ones that have high value and work to increase it.

Employees and volunteers are also extremely important stakeholders. Research shows that non-profit organizations are prone to staffing problems. At the root of the problems is difficulties attracting experienced employ- 
ees, who are willing to work either without pay or for nominal pay. If we assume that the number of individuals willing to work on a voluntary basis in a given geographical area is limited we may find that the value of the organization is one of the criteria determining their choice of the organization to which they will devote their time.

One may note a strong affinity between donors and employees in making a decision. Both goals and the ways of achieving them are important for both groups.

The other institutions that may be recipients of nonprofit enterprise values include the mass media moulding public opinion and influencing it. For them the value of our organization is certainly very important, since their task is to inform public opinion elsewhere about the organization's value. This group includes also other third sector organizations - that may both compete and cooperate with each other in realization of the goals. Those institutions cooperating with particular organizations, which may be called "service providers", are an important part of this group of institutions. These include banks, courier companies, postal services, specialized agencies providing services for various types of charity events and others. These companies will tend not be concerned with the value of a non-profit organization since they treat links with the organization on purely business terms.

Identification of the key stakeholders is just the first step in the process of increasing the value of a nonprofit organization. The next step is to manage the relationship between the organization and its stakeholders. Managing relationships with primary stakeholders, however, can result in much more than just their continued participation in the firm [22]. Research conducted by Hillman and Keim [22] has proven the hypothesis that stakeholder management is positively associated with shareholder value creation. In relation to non-profit organizations, Ospina, Diaz and O'Sullivan [34] point to stakeholders and external relations management as a source of effectiveness.

Balser and McClusky [3] conducted research which suggests that in a community in which information among stakeholder groups is shared, dealing with stakeholders using a consistent rationale based on serving public trust is perceived as a part of effective nonprofit organization management. It is also important to consider which value drivers influence its value as perceived by a specific group of stakeholders.

\section{Key value drivers of a non-profit organization}

Value drivers include each variable influencing the value of the organization. To make use of them it is necessary to group them in order to establish which ones are the strongest value drivers and to make individual employees responsible for the numbers.

The most important drivers are not constant and should be reviewed from time to time. (...) Determining the key value drivers may be difficult, since it requires adopting a new perspective in respect of the processes taking place in the organization. In many cases the reporting system of the enterprise is not able to provide the necessary information [14].

One should stress here that the value of the company is most commonly understood as the financial goal. To measure it, enterprise value methods, based mostly on discounted cashflows, are used. The value of the company is determined by future discounted cashflows, and increases only when the company makes wise capital investments, i.e. when the ROI is higher than the cost of capital [14].

It is similar with value drivers. Operational decisions, that is decisions shaping the structure of products, the level of prices, promotional actions, advertising, distribution and client service, translate in principle into three value drivers: the sales growth rate, operational profit margin and income tax rate. Investment decisions, for example regarding stock levels and any increase in production capability, are reflected in two value drivers: investment in working capital and fixed assets.

The cost of capital as a value driver depends not only on enterprise related risk, but also on financial decisions made by the management or on the problem of establishing the right proportions of indebtedness and own capital as sources of financing, as well as using the appropriate financial instruments. The last value driver, the value growth period, is the number of years estimated by the management when the return on investment rate will exceed capital costs [36].

The Polish authors mention numerous value drivers not of a strictly financial nature. Skoczylas [41], writing about the enterprise evaluation system in the value management environment, quotes a number of "strategic milestones", which she defines as non-monetary ratios, certain data exceeding the annual (budget) planning perspective that have to be reached in order to carry out the key actions or to be able to achieve a cer- 
tain status and level of monetary ratios. In other words, these are the key factors determining the value of an enterprise. These are sought in the area of marketing, production and supply, research and development, employment, financing, restructuring and organization and data processing.

Marcinkowska [32] presented an interesting attempt to encapsulate value drivers, providing at the same time financial and non-financial measures of identified variables. According to her, the main drivers are the following: Environment; Human capital, Organizational Culture; Strategy; Clients; Product, Quality, Innovation; Brand; Information and Information Systems; Strategic Alliances, Acquisitions, Mergers; the Natural Environment; Advertising and Public Relations.

Such extensive groups of drivers are justified in the case of commercial enterprises. For a third sector organization, though, they seem over complicated for everyday application and in the majority of cases simply do not correspond with their activity profile. In the literature (e.g. [18]) one can see the attempts to identify value drivers, useful in value management; although these are measures of activity, not value drivers. The authors base their work on the Balanced Scorecard methodology, which may be over complicated for the majority of small non-governmental organizations operating in Poland.

Without any doubt one should look for the value drivers among the assets of an organization, most of all among intangible assets. Pike, Roos and Marr [35], based on numerous literature sources, support such a hypothesis. Ashton [2] presents reviews of trends in value creation through human resources and intellectual capital. He examines intangible value and its ties to financial outcomes using the Skandia Business Navigator as a measure. The most important assets, i.e. those giving the organization a competitive edge, are the ones that meet the following four criteria: they should be valuable, rare, inimitable and the organization must be organized to deploy these resources effectively [5].

Most of the resources that meet the criteria are intangible assets. Barney [4] lists the following key assets of an organization: reputation, corporate culture, longterm relationships with suppliers and customers and knowledge assets. One of the first people to introduce the notion of intangible assets was Itami [24]. He singles out: technology, accumulated consumer information, brand name, reputation and corporate culture, arguing that these are the key assets of enterprises and the source of their competitive advantage. Nongovernmental organizations in Poland in particular are much less affluent with regard to material assets in comparison to companies from the other two sectors.

The report by the Klon/Jawor Association Podstawowe fakty o organizacjach pozarzadowych [Key facts on non-governmental organizations] shows that 8 out of ten organizations ( $81 \%$ ) say that they do not possess any material assets; this is much higher than in 2004, when $71 \%$ of the organizations indicated so; also only $3,2 \%$ of the organizations had some revenues from assets e.g. from renting premises, equipment, material rights, etc. [19].

Therefore, the intangible assets of non-profit organizations take first place, those that are not reflected in the company's balance sheet and which influence their value substantially.

One cannot disregard the key intangible asset of a company in discussing issues relating to the value of an enterprise. The material assets of the company (machinery, equipment, buildings) can be always replaced with new ones quite easily and fast, requiring only capital. Improving or replacing non-material / intangible assets is much more difficult. Cash is not enough in this case. Such assets as key competences or abilities, organizational culture or the quality of the organization developed in the company over the course of years and by numerous managers. One works on the intangible assets of an enterprise over years, engaging substantial capital. It is very difficult to replace them with new ones, as with a machine.

We should therefore assume that since these assets play such an important role in a modern organization they cannot be disregarded as a component of the value of the whole enterprise. The company's managers should be both aware of the existence of these intangible assets as well as possess the knowledge regarding their current value. The value of intangible assets is becoming one of the management parameters and managers in the non-profit organizations should focus their activities on it.

It seems, therefore, that the most important value drivers of a non-profit organization may be presented in the way shown in Table 1, dividing them into two principal groups. The first relates to the drivers that constitute the organization's assets and the second to drivers that are to a greater extent dependent on processing, transformation, i.e. on managing the assets. Such a division is justifiable if one considers the criterion of susceptibility 
Table 1. The key value drivers of a non-governmental organization (source: self study)

\begin{tabular}{|c|c|c|c|}
\hline \multicolumn{2}{|c|}{ RESOURCE-RELATED DRIVERS } & \multicolumn{2}{|c|}{ MANAGEMENT-RELATED DRIVERS } \\
\hline DRIVER & $\begin{array}{c}\text { STAKEHOLDERS - } \\
\text { RECIPIENTS } \\
\text { OF THE VALUES }\end{array}$ & DRIVER & $\begin{array}{c}\text { STAKEHOLDERS - } \\
\text { RECIPIENTS } \\
\text { OF THE VALUES }\end{array}$ \\
\hline $\begin{array}{l}\text { Human capital } \\
\text { (employees, } \\
\text { members, volun- } \\
\text { teers) }\end{array}$ & $\begin{array}{ll}\text { - } & \text { recipients } \\
\text { - } & \text { suppliers } \\
\text { - } & \text { cooperating } \\
& \text { institutions } \\
\end{array}$ & $\begin{array}{l}\text { Quality of the } \\
\text { management }\end{array}$ & $\begin{array}{ll}\text { - } & \text { suppliers } \\
\text { - } & \text { employees } \\
\text { and volunteers }\end{array}$ \\
\hline Leaders & $\begin{array}{ll}\text { - } & \text { recipients } \\
\text { - } & \text { suppliers } \\
\text { - } & \text { cooperating in- } \\
\text { stitutions } \\
\text { - employees } \\
\text { and volunteers } \\
\text { - members } \\
\text { and founding } \\
\text { members }\end{array}$ & Reputation/Image & $\begin{array}{ll}\text { - } & \text { suppliers } \\
\text { - } & \text { employees } \\
\text { and volunteers } \\
\text { - } & \text { cooperating } \\
\text { institutions }\end{array}$ \\
\hline Intellectual capital & everybody & $\begin{array}{l}\text { Organizational } \\
\text { structure }\end{array}$ & everybody \\
\hline Key competences & everybody & Action strategies & everybody \\
\hline
\end{tabular}

of the key value drivers to change. It is usually much more difficult to change the drivers that are part of organization's assets, taking into account the general difficulty in acquiring various assets, in particular for nonprofit organizations.

The drivers that can be subject to management are much more easily changeable - for example, by using the right techniques and methods of management. The groups of key stakeholders that are the most important recipients of the values created by individual drivers are assigned to the key value drivers. Defining the most important stakeholders, i.e. the ones whose view of the organization is most influenced by the particular driver, is impossible for some drivers. One should therefore assume that in those cases all the above defined groups are the key stakeholders.

The fact that human capital is one of the basic assets of each organization is no longer controversial. Since the 1970's there have been many studies, tests and management methods that take into account and concentrate on people who provide their work for the particular organization. The word "employees" is not used here on purpose, as in Polish non-governmental organizations only $26 \%$ hire paid employees [19], and not on- ly hired employees, but above all volunteers and members involved in work form the foundation of human capital.

The opinion of Krasnodębska, who argues one cannot imagine a well-functioning non-governmental organization without volunteers, is fully shared here. She also argues that voluntary work is one of the characteristic, even constitutive, traits of social organizations [29].

Analyzing the example of Teach for America organization, Hauser also claims that human capital is the most important asset of many organizations, in particular in the non-profit sector. Releasing the full potential of employees requires more than just idealism - effective managers are needed for this as well [21]. Bowman and Ambrosini [8] argue that the source of new use values is the labour performed by organizational members and that a firm's profits can be attributed to this labour.

Drucker (1994) also focuses human capital, claiming that this is the only asset that has the potential to grow. Within human assets, he stresses the role of managers, arguing that they are the ones forming the organization's structure, providing leadership and management spirit, that is the source of the firm's spirit. He com- 
pares a firm's goals to management's goals, maintaining that the effectiveness of an enterprise is the effectiveness of its management. Managers are the key assets of an enterprise and the most rare at the same time. Besides managers are employees, who are also an asset of an enterprise - if we view an employee as an asset comparable with other resources (the only difference being he/she is a human capital asset), by analogy we have to think how to use it most effectively.

Marcinkowska [32] notes that all the deliberations on enterprises and their achievements come from deliberations on human achievements - on the possibilities of the human mind and the results of cooperation to achieve a selected goal. We should stress that it is the power of people forming the organization that builds the power of the organization. Most of all it is the knowledge and skills of the employees of an entity (including the management's) and the ability to motivate them to use their competence for the enterprise's development that determine the value of the entity, its competitive standing and market power. The philosophy of human resources management is to acknowledge that employees are one of the most valuable elements of an enterprise.

All the categories of people involved in the past in the organization's activity, i.e. its members, employees and volunteers should be included in the human capital category. Former non-profit organization members are a significant and usable source of valuable assets: knowledge, contacts, time, funds or simply human potential [11].

The activity of numerous non-profit organizations is determined by its leaders. A very strong role of one or several leaders who decide on a majority of issues is noticeable. The MONAR-MARKOT Association and its founder and leader Marek Kotański is a good example.

Monar Association is a non-governmental, apolitical organization, operating throughout Poland. The association deals with a multi-aspect system of preventing drug abuse, homelessness, helping people infected with the HIV virus, people with the AIDS syndrome, terminally ill, lonely and with other threats of social character. In cooperation with the Central Management of Prison Workers it implements programs in penitentiary institutions and offers therapeutic help to people leaving prisons. Throughout Poland Monar carries out loss reduction programs: exchange of needles and syringes, handing out condoms, health counseling, educa- tion and information. Its task is to help people in a very difficult life situation. The founder and the guiding spirit of all of the MONAR's activities was Marek Kotański (died in 2002). He was also an unquestioned authority, always present in the mass media, on the issues of drug abuse, people infected with HIV virus and the homeless. His statements built up a social awareness of the above phenomena. After he died, although MONAR continues its activity, it is no longer as visible in the mass media, and its new activities, equally spectacular as in the past, are less visible.

Especially in the context of non-profit organizations one should remember that it is not via the letters, analysis, goals, result measurement systems, etc., that the leaders inspire and motivate employees. Such activities are more connected to the notion of "management" rather than "leadership". People are inspired by exciting visions of the future, with values that the organization can create, lofty ideas - it is a good leaders' task, that is those who want to be leaders of their organizations, to create them.

Activities aimed at increasing the quality of human capital will influence the value of a non-profit organization, especially value perceived by the recipients of activities, by the suppliers and representatives of cooperating institutions.

An investment in the "Leadership" factor will bring about an increase in the value of an organization also in the eyes of the other stakeholders' groups, namely founders, members and the employees themselves of a non-profit institution.

The notion of intellectual capital, defined as the knowledge of employees and management, is directly connected to human resources. Intellectual capital is the resource that stems from relationships between stakeholders and partners, from the organization's ability to innovate and manage change, from its infrastructure and from the knowledge, experience and transferable competencies of its staff [27]. It is a resource of strategic importance, influencing the competitive position and potential of every organization. At the same time it is very difficult to evaluate and very easy to lose. One can distinguish the following layers of knowledge in an organizations: information, news and data; lists, studies, databases or sets of information, news or data; ideas and thoughts (in particular hypothesis, suggestions, concepts); detailed solutions of various types; management style and procedures; methods of action; particular characteristics [12]. 
One cannot overestimate the role of intellectual capital for a non-profit organization. With the use of the above knowledge layers, one may give specific examples of its indispensability for a fundraising institution. Knowledge, focused in the information, news and data layer, is the source of ideas and thoughts, i.e. those aspects of activity aimed at raising the interest of donors and creating the desired reaction. All the databases, such as address database, will be used by the organization to send invitations to charity events, leaflets encouraging the possibility of tax deductions, etc. Detailed solutions are fundraising methods, such as auctions, works of art, charity balls and others.

The key competences allow the organization to quickly accommodate changes in the environment. Kozińska and Żor [28] describe the competences of an organization as the set of knowledge, skills and inter-structural and interpersonal relations, internal and external that the organization possesses and that are grounded in its culture and its people's behaviour that allows the organization to fulfill tasks and achieve its goals in a manner characteristic of the particular organization.

Competences include the following components: knowledge used in work; experience; abilities and predispositions towards, above all, cooperation in achieving

the company's goals, the ability to act professionally; cultural (ethical values) [37].

In recent years, theories arguing that the realization of an organization's goals, including its survival and effective existence, depend on the competence resources it possesses have became very fashionable. All enterprises in a market economy in a constant battle for clients all seek to achieve competitive advantage. The look for the sources of this advantage in the first instance in its environment (new markets, financing sources...). Unfortunately, changes in the environment affect all enterprises competing with each other. Therefore, enterprises increasingly often turn to themselves to the sources of their competitive advantage within the organization - namely to competences.

It is of particular importance for the specific enterprises active within the third sector. In this sector one seeks ways of resolving social problems, keeping up with market principles and helping the weakest at the same time. The concept outlined by Burton Weisbrod is one of the most important economic concepts explaining the existence of social organizations. In the specialized literature it is known as public goods theory, or the market failure/government failure theory [30]. Generally speaking, social organizations take up that area of economy where the market mechanism turns out to be imperfect. Therefore, they have an extremely responsible task to fulfill thanks to the key competences they possess and develop [40].

Key competences and intellectual capital are the value drivers that are of interest for practically all the organization's stakeholders. It is the knowledge and skills of employees and leaders that the effectiveness of the activities undertaken by the organization depends upon. One does not need to prove that the greater the employees' experience and the better the ideas of leaders, the better the programs implemented by the organization and the better its financing will be.

Another area that brings the possibility of identifying intangible components of an enterprise is the quality of management.

It has been proven many times that if one compares enterprises from the same sector with similar resources and market position, the factor that most accurately explains the differences in results achieved is the way enterprises are managed. Why is it so that barely known organizations develop dynamically to become the largest in their sector while others, previously with a good name, fall into decline and are taken over by others or even go bankrupt? The factor that usually differentiates them is the method of management, in fact the quality of the management, which is becoming the key issue.

Although the quality of management has not been explicitly defined in the literature it is an important, and still open, problem of theory and practice in change management in enterprises and institutions. The quality of methods and tools used by managers determines the effectiveness of decisions vital for the market position of the companies and the atmosphere among employees. Therefore, measures of the effectiveness of an organization's management in the changing market environment are widely sought after [38].

Sajkiewicz [38] gives a several indicators of the quality of a company's management: structures to directly contact clients; conceptuality of management; open communication systems; cooperation in problem solving; constant education; leadership roles in improving the organization; the organization's culture strategy, with its ethical content; orienting processes towards the clients; modern management methods; computer networks for internal and external communication; decentralization of power and flexibility of the structures; 
a broad spectrum of incentive instruments; competences in line with the requirements and rational division of labor.

It seems that this area is one that should be developed in non-profit organizations, in particular Polish ones. One of the common problems of non-governmental organizations is resolving the dilemma of finding a happy medium between modern management of the organization and potential loss of flexibility, innovation and the spirit of cooperation and abandoning its mission.

Also in Poland the problem is becoming increasingly important. The main reason for this is withdrawal of foreign funds from activity in Poland. The possibility of using European Union funding has not so far brought any great effect (the above quoted study [19] shows, that as few as $4.5 \%$ of the organizations have used this source of financing in the last four years).

Another reason for the growing need to apply modern management techniques is the growing expectations of donors, both public and private. Increasingly often they require the sponsored organization to use measures of effectiveness and results of its activity [7]. These indices can be increased through more effective management.

Why do donors far more willingly respond to appeals of certain non-profit organizations, at the same time ignoring the applications and requests of others, with similar ideology? Why, with a choice of several foundations with identical goals, e.g. helping ill children, do they extend their support to this one and not another? These questions become quite simple when we pay attention to the organizations that tend to be preferred by donors.

It turns out that they are usually e.g. widely known foundations, with relatively long history and having a good "reputation". In the enterprises sector, this mysterious reputation attracts purchasers like a magnet, as a result clients, having a choice between identical products of two different companies, usually choose the merchandise of a well known company, even paying a higher price. As a result, the client pays for the reputation of the merchandise, as the difference in the price reflects this intangible value purchased by him/her.

In the literature one can find many notions with a similar meaning. These are: brand, image, reputation, goodwill.

Goodwill is explained, for example as: the value of the enterprise in inventory, reputation and connec- tions [43], commercial privileges of the company, being the outcome of a thriving enterprise [23].

Dowling [15] presents an interesting argument to support the hypothesis that reputation has a direct influence on the value of an enterprise. The two principal approaches to goodwill valuation that are widely accepted in the academic literature and in the best accounting practice examines Taliento [43].

The image of a non-profit organization may be viewed as an aspect of competitiveness. Not only when one competes for donors, but also for other resources available on the market. The above mentioned human resources spring to mind here. When the number of volunteers willing to work is limited in a particular local area it is, among other things, the image of the organization that will influence their choice of foundation or association and the activity in which they choose to participate.

On the other hand, the negligence of a nongovernmental organization to inform the environment (...) may result in loss of trust and social support [25]. It is due to its extremely highly [valued] image - measured by the knowledge of the organization and trust of Poles for the institution [33] - Wielka Orkiestra Świątecznej Pomocy $^{2}$ (The Great Christmas Charity Orchestra) is one of the leaders among non-profit organizations in the category of funds raised.

"Wielka Orkiestra Światecznej Pomocy" is the largest and most prosperous charity organization in Poland. Its objectives, included in the status document, are saving children's lives, health promotion and education in the field of preventive treatment. Between 1993 and 2006 The charity has collected and spent over $\$ 65 \mathrm{mln}$ on saving lives. Besides humanitarian work, it is also a powerful medium spreading an ideology of kindness, friendship, tolerance, and openness.

Therefore, image, as value drivers mainly influence donors, sponsors and other institutions, provides funds for non-profit organizations.

Another value driver of an organization, part of the group susceptible to management, is organizational structure. Organization is not a goal in itself, it is a means to an end, which is achievements and business results. Organizational structure is an indispensable element, a flawed structure may substantially lower the productivity of a business and even destroy it [16]. Each, even the smallest non-profit organization, must have a certain organizational structure. Often the exist- 
ence of the structure is forced by e.g. the statute of an organization, where at the least a Management Board must be appointed. Associations have frequently, besides the Management Board, also a Presiding Board, an Audit Committee, Accounting, then Branches, etc. Fundraising sections or sections implementation individual statute objectives may be set. It is worth quoting the main determinants regarding non-governmental organization structures provided by Bogacz-Wojanowska [7], quoted by Wilson [45]:

- size - in the case of small organizations there is no need to split tasks and as a consequence to differentiate [organizational sections]; when the organization grows, it starts to feel such a need, since everybody cannot all the time deal with everything. There are groups or people assigned, responsible for the individual objectives of the organization,

- technology (physical objects and tools, equipment, also knowledge),

- the environment of the organization - its nature also conditions the size of differentiation and integration of non-governmental organizations,

- a stable environment creates favourable conditions for bureaucratic structures, or structures of high vertical differentiation, while a turbulent and unstable environment requires certain adhocracy (temporariness), decentralized structures,

- age of the organization - in the course of years organizations change their social structures,

- financial dependency - the more organizations depend on one, external, source of financing, the more centralized their structure will be,

- strategies - a type of realized strategy of action obliges the creation of specific organizational structures.

Organizational structure seems to be mostly responsible for the relevant flow of information in each organization. A clear hierarchy structure, clarity of official relations translates into quick and efficient and multidirection flow of information resources. Therefore, it influences the efficiency of actions and therefore any improvements in the organizational structure will increase the value of non-profit organization in the eyes of all groups of stakeholders.

The last of the main value drivers of a non-profit organization one should pay attention to are strategies. This notion should be understood as specific ways to achieve the organization's objectives, together with the resources necessary to achieve them. At the least, we can talk about:

- product strategies - in the case of a non-profit organization these are usually services strategies, aimed at maximizing their quality,

- communication strategies - or methods of informing broadly understood environment/public about its mission, activities, values, etc.,

- fundraising strategies - or activities aiming at providing the organization with the necessary financial means, in connection with specific activities, but also for everyday operations,

- personnel strategies - directed at increasing the quality of human capital.

From a more general point of view regarding the choice of a development path of a given organization we may use the classification of strategies that proposes four variants of activities [1]: market penetration strategy; market development strategy; product development strategy; diversification strategy.

The relationship between the strategy and the value of the organization has been subject to many studies. Lubatkin and Chatterjee [31], among others, examine the stability of the relationship between strategy and shareholder value; Bowman and Ambrosini [8] consider the role of strategy in the context of the value creation process.

It seems that non-profit organizations may use almost all of the above strategies. The activity of Stowarzyszenie Przymierza Rodzin (the Families Alliance Association) is an example of applying most of them:

Stowarzyszenie Przymierze Rodzin is an all-Poland non-profit organization operating since 1983. The work of the alliance is carried out mostly among peer groups of children and young people, parents' groups and families groups, run in the Local Families Alliance Centers at parishes. Currently, about 20 centers are active, grouping about 1500 people. The children and young people's groups (about 500 persons in 20 groups) are run to a large extent according to the scouting method.

The objective of the educational program is the spiritual, intellectual and physical development of children. The tutors are young people, mostly students, and their helpers are chosen from the upper high school. All the tutorial staff (about 80 people in the whole association) work on a volunteer basis. In order to increase their tutorial abilities, courses, training sessions and seminars are organized. 
There are about 50 young people attending the courses for tutors and helpers each year. Another objective of the alliance's activity is educational and cultural activity. Currently the alliance runs three primary schools, three lower secondary schools, two general education upper secondary schools, one college, two youth community centers and one kindergarten.

The association uses diversification, placing its activities in various areas (education - running schools and at the same time supporting youth community centres and simultaneously supporting and educating activity in local centers associated with parishes). It uses a market development strategy (starting educational activities at primary schools, then broadening it to kindergartens and colleges and opening new primary and lower secondary schools) and finally the product development strategy (besides concentrating on education in primary school, it also organizes summer trips, youth groups, etc.).

In the context of value management the process of working out the strategy, especially the means used for its evaluation, has to be directed at maximizing value.

The strategy should above all include an explanation of how the entity intends to gain an advantage over other entities, which would lead to increasing its value. Such an explanation should be grounded in full market analysis, analysis of other organizations active on the market and current advantages and the possibilities of the entity. The strategy should also include the value management elements:

- interpretation of the strategy evaluation results and assessment of the main assumptions that have influenced its value,

- measuring the value of rejected strategies and the reasons for rejecting them,

- establishing the need for resources,

- summary of predicted results of strategic plans, in particular including forecasts regarding the main value drivers,

- analysis of several different scenarios to help foresee dangers or new possibilities and their influence on strategies implementation [14].

\section{Conclusion and future research}

An objective of presentation of the key value drivers of non-profit organizations was above all aimed at drawing attention of organizations to the fact that it is not only human resources and reputation that are the main success factors. The presented classification does not aspire to be comprehensive and exhaustive. The line between separate drivers are certainly also fluid. For example, the notions of intellectual capital and key competences interpenetrate in a certain manner.

A well organized structure certainly depends on the quality of its management, which in turn depends on the leaders of the organization. However, identification of a larger number of value drivers should help to increase the value and help the non-profit organization in succeeding. The increase of its value may be considered the measure of success of a particular nonprofit organization. In no way does it contradict other, specific, goals and missions, formulated by third sector entities.

We should only assume that an activity should be undertaken when it increases the value of the organization in the perception of at least one of the stakeholder groups listed first above. In such a way, reaching every goal, be it training for the unemployed, the purchase of medical equipment or securing workplaces for handicapped people, will increase the value of the non-profit organization. At the same time, awareness of the existence of a higher purpose or increasing value will help to focus not only on short-term goals but will help nonprofit organizations' to gain in a long-term, strategic way.

The aim of building up value for stakeholders, presented to the environment in an appropriate manner, should also help raise funds and convince sponsors and donors that these are the organizations worthy of support. It also allows organizations to build long-term relationships between donors and the organization,by informing them in an open and clear manner about the influence of individual activities on the increase in the value of the organization they sponsor. Therefore, value becomes a measure of the effectiveness and efficiency of activity, which may be extremely helpful in day-today operations of each non-profit organization.

Future research may concentrate on other stages of value management and on working out the concept of their implementation in non-profit organizations. The value management process consists in principle of three stages [36]. The first of them - gaining involvement - aims at attracting all the participants of the organization: its leaders, members, employees and volunteers to the value management concept. They should be convinced 
that an increase in value is the main and universal purpose of activity.

The second stage is assessment of value. After the key value drivers have been identified they should be evaluated and their value measured. Then the strategic and operational planning process takes place, or the strategies that will lead to achieving the organization's goals and respective detailed action plans are created. All of that should be done in parallel with training sessions on creating value for stakeholders. The result of this stage is the list of key value drivers, the result of the value assessment and operational strategies and plans.

The stage known as instilling principles is directed at keeping the introduced changes. The result of this will be clearly established result indexes, both financial and organizational, and a compensation (motivation) system correlating with any increase in value. It requires definition of the role of individual sections in the organizations in increasing value and the measure of the results of the organization and compensation systems. Also at this stage training sessions, concentrating on focusing attention of each one of them on their individual roles in increasing value, are necessary.

\section{References}

[1] Ansoff H.I. - Corporate Strategy. McGraw-Hill, New York 1965.

[2] Ashton R. - Intellectual Capital and Value Creation, A Review [in] Journal of Accounting Literature, No. 24, pp. 53-134, 2005.

[3] Balser D., McClusky J. - Stakeholder relationships and nonprofit organization effectiveness [in] Nonprofit Management and Leadership, No. 15, pp. 295-315, 2005

[4] Barney J. - Organizational culture: can it be a source of sustained competitive advantage? [in] Academy of Management Journal, No. 28, pp. 656665, 1986.

[5] Barney J. - Firm resources and sustained competitive advantage [in] Journal of Management, No. 17, pp. 99-120, 1991.

[6] Blanchard K., O’Connor M. - Managing by Values. Berrett-Koehler Publisher, San Francisco 1997.

[7] Bogacz-Wojtanowska E. - Zarzqdzanie organizacjami pozarzqdowymi na przyktadzie stowarzyszeń krakowskich. Wydawnictwo Uniwersytetu Jagiellońskiego, Kraków 2006.

[8] Bowman C., Ambrosini V. - Value Creation Versus Value Capture: Towards a Coherent Definition of Value in Strategy [in] British Journal of Management, No. 11, p. 1-15, 2000.
[9] Bowman C., Ambrosini V. - Firm value creation and levels of strategy [in] Management Decision No. 45, pp. 360-371, 2007.

[10] Bryson J., Gibbons M., Shaye G. - Enterprise Schemes for Nonprofit Survival, Growth and Effectiveness [in] Nonprofit Management and Leadership, No. 11, pp. 271-288, 2001.

[11] Chou A., Jordan Ch., Kilpatrik A. - Ukryte zasoby organizacji pozarzqdowych [in] Trzeci Sektor, No. 6, pp. 100-103, 2006.

[12] Ciupa S.W. - Ile kosztuje wiedza menedżera? [in] Manager : pismo szefów i kadry zarządzającej, No. 4, pp. 20-24, 1997.

[13] Clarkson M. - A stakeholder framework for analyzing and evaluating corporate social performance [in] Academy of Management Review, No. 20, pp. 92-117, 1995.

[14] Copeland T., Koller T., Murrin J. - Wycena: mierzenie $i$ kształtowanie wartości firm. Wig- Press, Warszawa1997.

[15] Dowling G. - How Good Corporate Reputations Create Corporate Value [in] Corporate Reputation Review, No. 9, pp. 134-143, 2006.

[16] Drucker P.F. - Praktyka zarzadzania. Akademia Ekonomiczna, Kraków 1994.

[17] Drucker P.F. - Zarzqdzanie organizacja pozarzqdowa - teoria i praktyka. Wyd. Fundusz Współpracy, Warszawa 1995.

[18] Evans M. - Creating Value In the Nonprofit Sector. http://www.exinfm.com, 24 July 2007.

[19] Gumkowska M., Herbst J. - Podstawowe fakty o organizacjach pozarzqdowych. Raport z badania. Stowarzyszenie Klon/Jawor, Warszawa 2006.

[20] Harris I., Mainelli M., O’Callaghan M. - Evidence of worth in non-profit sector organizations [in] Strategic Change, No. 11, pp. 399-410, 2002.

[21] Hauser J. - Lekcja organizacji w sektorze nonprofit [in] Trzeci Sektor, No. 4, pp. 77-83, 2005.

[22] Hillman A., Keim G. - Shareholder value, Stakeholder management, and social issues: what's the bottom line? [in] Strategic Management Journal, No. 22, pp. 122-139, 2001.

[23] Hornby S., Cowie A.P. - Oxford Advanced Learner's Dictionary of Current English. Oxford University Press, PWN (reprint), Warszawa 1981.

[24] Itami H. - Mobilizing Invisible Assets, Harvard University Press, Cambridge 1987.

[25] Iwankiewicz-Rak B. - Siła wizerunku organizacji pozarzqdowej, Trzeci Sektor 5, 2006, p. 30-36.

[26] Kearns K. - The Strategic Management of Accountability in Nonprofit Organizations: An Analytical Framework [in] Public Administration Review, No. 54, pp. 185-192, 1994.

[27] Kelly A. - The intellectual capital of schools: analysing government policy statements on school improvement in light of a new theorization [in] 
Journal of Education Policy, No. 19, pp. 609-629, 2004.

[28] Kozińska A., Żor A. - Niewidzialne aktywa organizacji. Projekt, Warszawa1998.

[29] Krasnodębska J. - Zarządzanie wolontariatem rady praktyka [in] Trzeci Sektor, No. 4, pp. 84-90, 2005.

[30] Leś E. - Organizacje społeczne, studium porównawcze. Program Phare Dialog Społeczny NGO's, Warszawa 1998.

[31] Lubatkin M., Chatterjee S. - The strategyshareholder value relationship: testing temporal stability cross market cycles [in] Strategic Management Journal , No.12, pp. 251-270, 1991.

[32] Marcinkowska M. - Ksztattowanie wartości firmy. Wyd. Naukowe PWN, Warszawa 2000.

[33] Nowotny S. - Wizerunek trzeciego sektora $w$ opinii publicznej [in] Trzeci Sektor, No. 5, pp.7-29, 2006.

[34] Ospina S., Diaz W., O’Sullivan J. - Negotiating Accountability: Managerial lessons form identitybased nonprofit organizations [in] Nonprofit and Voluntary Sector Quarterly, No. 31, pp. 5-31, 2002

[35] Pike S., Roos G., Marr B. - Strategic management of intangible assets and value drivers in $R \& D$ organizations [in] R\&D Management, No. 35, pp. 111-124, 2005.

[36] Rappaport A. - Wartość dla akcjonariuszy. Poradnik menedżera i inwestora. WIG-Press, Warszawa 1999.
[37] Sajkiewicz A. - Człowiek - kreator wartości przedsiębiorstwa [In] Zarządzanie wartością firmy (ed. Herman, A., Szablewski, A.). Poltext, Warszawa 1999.

[38] Sajkiewicz A. - Jakość zarzqdzania przedsiębiorstwem. Wyd. SGH Warszawa 1999.

[39] Sargeant A. - Marketing $w$ organizacjach non profit. Oficyna Ekonomiczna, Kraków 2004.

[40] Semeniuk Z. - Klienci rynku przemysłowego, Świat Marketingu, www.swiatmarketingu.pl, 05-2004.

[41] Skoczylas W. - Wartość przedsiębiorstwa w systemie jego oceny. Uniwersytet Szczeciński, Szczecin 1998.

[42] Stanisławski J. - Wielki słownik angielsko-polski. Wiedza Powszechna, Warszawa 1983.

[43] Taliento M. - Measuring Goodwill: Rationales for a Possible Convergence between the Excess Profits Estimate and the Residual Value Approach [in] The Journal of American Academy of Business, No. 10, pp. 197-203, Cambridge 2006.

[44] Wawrzyniak B. - Odnawianie przedsiębiorstwa na spotkanie XXI wieku. Poltext, Warszawa1999.

[45] Wilson D.C. - Organizational Structures in the Voluntary Sector [in] Issues in Voluntary and Non Profit Management (ed. Batsleer J., Cornforth C., Paton R.). Addison-Wesley, Wokingham 1992. 